\title{
Home vs. Cross-Border Takeovers: Is There Any Difference in Investor Perception?
}

\author{
ATM Adnan *
}

\begin{abstract}
:
This paper attempts to portray the empirical difference in investors' perception towards the cross-border and domestic merger and acquisition (M\&A) announcements of UK acquirer firms reflected through the significant abnormal stock return. The researcher conducts a short-run event study on the daily stock return of 100 UK bidding firms (50 involved in domestic and 50 involved in crossborder M\&As between 2015 and 2016) to compare any significant abnormal returns (AAR and CAAR) around the event announcement period. National and international mergers and acquisitions have witnessed a considerable expansion globally, with the United Kingdom being one of the pioneers in the worldwide market for corporate domination. Research results exhibit that in domestic M\&A bidding, firms experience a significant positive announcement return (CAAR) in the event window $\left(t_{1}-t_{0}\right)$ redolent to the positive expectation of investors from the M\&A transaction. However, the post-announcement negative return concurrently proves the initial overreaction of investors and the semi-efficient market hypothesis. Foreign M\&As result in an insignificant positive return (CAAR) in all the three event windows. There was existence of a positive trend in the cross-border preevent return (AAR) indicative of narrow possibilities of insider trading or investors' optimistic anticipation, but this is not significantly conclusive.
\end{abstract}

Key words: Mergers and Acquisitions; Cross-border; Domestic; Shareholders; Abnormal return.

JEL classification: G14, G34.

\section{Introduction}

As the world capital and product market become more integrated along with the rise of new economic zones and markets, internationalisation has become an effective and prudent business strategy for firms to establish an effective corporate control over the global corporate assets (Moeller and Schlingemann, 2005). Both cross-country and domestic merger and acquisition (M\&A) has been a prevalent approach for companies to get access to the global resources in order to achieve the competitive edge. M\&A can be simply defined as a combination of firms or a transfer of ownership and management control between firms through acquisition of the majority of the shares or assets (Wübben, 2007). The firm that is acquiring is called the "the bidder" or "the acquirer" and the other one is called "the target".

ATM Adnan; Bangor University, Bangor Business School, College of Business, Law, Education and Social Sciences, Bangor University, Bangor, Gwynedd, LL57 2DG, Wales, UK, <atmadnan@outlook.com>. 
When the so-called fifth merger wave has started in 1990s, M\&A has become a highly acceptable strategy due to the dynamic growth of international trade, technological advancement and globalisation (Hitt et al., 2001); (Child and Tse, 2001). With the increase of M\&A, research associated with effect of this event on the firms' performance and growth has also gained in momentum. Nowadays it is one of the most researched areas in the corporate finance and accounting. Majority of the research have primarily adopted an event study to analyse the M\&A effect on the target and acquirer firm's shareholder value creation. After the instigation of this method by (Fama et al., 1969), it has been broadly used by researchers to detect the investors' reaction (McWilliams and Siegel, 1997) towards the announcement of major corporate events in order to draw a conclusive argument on whether an event has a positive, negative or no effect on the shareholder value (Brown and Warner, 1985). Abnormal return is the key element of event studies which shows the difference between the actual and expected return, calculated on the stock price over the event period. The fundamental assumption of this method is that any news associated with corporate events will instinctively draw attention of the investors and it would be reflected in the market return of the common equity (MacKinlay, 1997) as a measure of the shareholders' wealth.

In this paper, the author tries to portray the investors' perception towards the domestic and cross-border $M \& \mathrm{~A}^{1}$. A traditional event study is used to find out whether shareholders are more responsive to the event announcement of bidding firms involved in the acquisition of domestic or foreign firms. Interest on this issue is generated due to the fact that $\mathrm{M} \& \mathrm{~A}$ transactions have become more global than local. Almost $80 \%$ of the foreign direct investment (FDI) of industrialised countries (Hudgins and Seifert, 1996) are in the form of M\&A rather than green field operations (Conn, 1985). The most probable reason could be expectation of a greater value through the competitive advantage in the cross-border rather than domestic acquisition as market imperfections exist (Kang and Johansson, 2000). But interestingly, empirical findings are not supportive of this theory and e.g. (Andrade et al., 2001) argues that cross-border M\&A generates significant gains for target firms compared to neutral or negative gains for the bidding firms' shareholders.

There could be many reason behind this difference such as investors' expectations about the application of a distinct management policy and techniques towards achieving the scale of economies (Scherer and Ross, 1990), fear of a loss of control (Ravenscraft and Scherer, 1987), financial interaction, economic policy issues such as taxation and agency cost (Capron et al., 2001).

1 Domestic M\&A occurs between firms whose bases of operation are in the same country while cross-country mergers take place between firms which headquarters are situated in different countries. 
The primary objective of this study is to identify whether investors (shareholders) are more reactive towards the event news of firms involved in domestic mergers or cross-country mergers. Secondary objectives are to analyse the stock price movement of the acquirer firm to identify any significant abnormal returns associated with the merger announcement and to identify any leakage of event information prior to the public announcement along with the sign of any insider trading due to information asymmetry.

The main discovery of this research paper is that the UK acquirers do not earn statistically substantial positive abnormal returns in the short-run. Over the last three decades, a considerable number of studies on value generation of national and international mergers and acquisitions have been carried out but only relatively few focused studies were carried out on M\&A outcomes relevant to the UK conditions. This research presents one of the latest attempts to observe the payoff of domestic and international M\&As in the UK and makes a noteworthy contribution to the cross-border M\&A literature.

The paper advances as follows: the second part presents a literature review. The next part contains numerical calculations and procedures followed by the experiential findings and analysis of the results. The last part forms the conclusion which integrates ideas for the future research.

\subsection{Literature review}

In the broader stream of accounting and finance research, an event study has been used for various firm-specific and macroeconomic events, such as dividend announcements, mergers and acquisitions, issuances of a new stock or debt, or economic and political announcements such as changes in the tax and interest rates. Apart from the field of accounting and finance, event studies have also been popular in other fields such as law (Schwert, 1981b); (Kothari and Warner, 2004) and economics (Mitchell and Netter, 1994); (Schwert, 1981a). However, its primarily application is devoted to analysing the effects of stock price reactions of the firm in response to a public announcement.

An event study is based on the idea of how an event changes the worth of the firm. The concept states that any impact of the event will be reflected on the share price (other variables also exist but the stock price is dominant) of the company in an efficient market environment and this can be measured by the abnormal market return (the key element of the method), but the peripheral factor must be considered as well to isolate the effect of the actual event (Serra, 2002).

In this study, the author focuses on M\&A as a financial event and its effect on the shareholders' perception towards the investment decision in the acquirer firm, reflected in the stock price. There are primarily two acquisition theories. Within the first one, the management focuses on the growth of sales and control over the 
market. Economic gain is not segregated among the bidding and target firms or the cost associated to a negotiation and risk. The second acquisition theory focuses on the value maximisation. It states that there should be expected an economic value addition from the M\&A. Both firms will earn at least the expected rate of return regardless of the market condition (WESTON and HALPERN, 1983).

To measure any gain or loss resulting from the M\&A event, four basic measures are followed. First, these is an 'event study' which observes the abnormal return to investors around the transaction period and can be used for both the shorter and longer event horizon (Haleblian and Finkelstein, 1999). Next there is the 'accounting based method' which compares the financial statements of the firms during both the pre- and post-event period in order to identify the change in the financial performance indicator such as profitability, efficiency, liquidity, credibility, leverage and market performance (Zollo and Singh, 2004). Thirdly there is the 'survey of executives', also called the managers' subjective assessment, which involves getting the perception of the sample panel of managers about the perceived value generated from the M\&A through a standard questionnaire (Homburg and Bucerius, 2006). The last measure represent clinical studies which are basically an extensive and in-depth survey of the top executives and conversant observers (Bruner, 2002).

Every M\&A typically tries to achieve three fundamental roots of synergies (Lubatkin, 1983). The first and most commonly known source are 'technical economies' incurred when the tangible process alteration results in more output from the same input (Shepherd, 1982). The second basis cames from 'pecuniary economies' related to the vertical and horizontal integration with the aim to establish a control over the suppliers and buyers (Porter, 1980). The third basis are 'diversification economies' which represent a trade-off between the risk and firm's performance. (Rumelt, 1974) argued that in order to achieve a positive diversification effect of the merger, there should be a strategic fit and unified characteristics between the acquirer and the target firm (Salter and Weinhold, 1979).

Contemporary event studies are more adopted in the capital market research with a view to test the market efficiency. Absence of any abnormal stock returns following the particular corporate events logically indicates inefficiency of the capital market (Brown and Warner, 1980). Event studies aiming at long limits can provide important evidence of market efficiency (Fama, 1991). Long-term event studies aim at recognising if certain events affect asset prices over long periods of time, i.e., several months or years. Thus, they can be interpreted as tests of performance persistence.(Ritter, 1991, Loughran and Ritter, 1995),(Franks et al., 1991, Rau and Vermaelen, 1998b). 
Following the introduction of an event study to the wider arena of accounting and finance scholars by (Ball and Brown, 1968) and (Fama et al., 1969), there have been many prudent methodological changes in the event study approach, but the original ideology remained the same. According to (MacKinlay, 1997), the first ever event study was presented by (Dolley, 1933) and exhibited the stock price response following the split. This has been also noted by several published papers in the early 1950's and 1960's, e.g. (Myers and Bakay, 1948), (Ashley, 1962). There are no authentic data on how many event studies were altogether done, but according to (Kothari and Warner, 2005) in total 565 research papers were published in the five major finance journals over the period 1974-2000. However, apart from the broader finance and accounting arena, event studies have been frequently used also in other research fields. (Schwert, 1981b); (Corrado, 2011).

As far as the event study is concerned, it is primarily engaged in analysing the stock price movement in order to calculate the abnormal return and to draw a conclusion regarding the gain or loss (value addition) of the participating firms in M\&A. (Kothari and Warner, 1997) in their event study of 3,688 completed mergers for both long and short time horizon found that in general, M\&A creates value for stockholders but they also found that in every transaction, target firms are the ultimate gainer with the average abnormal return (AAR) of 16\% (3 days event window) to $24 \%$ (longer event window), which is statistically significant at the $1 \%$ level. In contrast, the AAR for acquiring firms is $-0.7 \%$ (3 days event window) and $-3.8 \%$ (longer period). Although the AAR is negative for bidding firms, it is not conclusive that the acquirer firm's shareholders are losers, but it can be surely said that they are not gainers like the target firm's shareholders. Contemporary studies of (Andrade et al., 2001), (Ruback, 1983), (Jarrell et al., 1988) come up with similar findings.

Another viewpoint that differentiates performance is based on the book-to-market ratio (B2M). Higher B2M firms are known as value firms which tend to have a higher return whereas lower B2M firms are known as growth firms with a lower return. Research findings offer inconsistent clarifications of this phenomenon. While (Fama and French, 1992) argue that abnormal returns are due to the higher risk, (Lakonishok et al., 1994) suggest this is due to an overvaluation on the basis of the past performance. Empirical findings related to three years of abnormal returns by (Rau and Vermaelen, 1998a) show the average abnormal return of $17.3 \%$ for a growth acquirer against $7.6 \%$ for value firms, which is consistent with the theory. (Stillman, 1983) tries to identify the potential monopoly effect on the stock return in the case of a merger between two parallel competitors. He showed that there has been a significant positive cumulative abnormal return (CAR) for the target competitor firm between -20 and +10 days relative to the event announcement. Findings of (Eckbo, 1983) opposed the prior findings by 
eliminating the competing firms from the sample and he finds no significant evidence of an abnormal negative return. Thus he concludes with the argument that more corporate control rather than reduction in market competition is the reason behind the merger gain. (Jarrell and Poulsen, 1989) studied a sample of 663 successful M\&As from the period 1960-85 and found that there are more than $20 \%$ AAR for the target firms' shareholders in comparison to almost nil return for the acquirer firms' investors.

Forms of payment in M\&A transactions are another interesting basis on which to investigate the return variance between bidder and target firms. (Gordon and Yagil, 1981) find considerable gain difference between the cash and stock acquisitions. They find that the "CAR value in stock merger is $5.3 \%$ for the bidder and $18.7 \%$ for the target, whereas in the cash merger the values are consecutively $7.9 \%$ and $31.9 \%$ ". A similar result with a significant difference is also exhibited by (Wansley et al., 1987) on the target firms' gain variance on the basis of the payment form $(38.65 \%$ for the cash and $25.39 \%$ for the stock merger). The scenario seems to be more adverse in the case of a long-term stock yield variance. (Loughran and Vijh, 1997) find the AR of $(-24.2 \%)$ for the stock merger and $18.5 \%$ for the cash merger covering the five years of the post-merger period. So in general the stock merger is characterised by a negative or less abnormal return. The probable underlying reason as suggested by (Myers and Majluf, 1984) is the "information asymmetry" and difference in perception between stockholders and managers. Whereas managers try to issue the stock in M\&A when they know it is overvalued, stockholders perceive that stock issue will result in a decrease in the stock price. Drawing any conclusion solely based on the form of payment would be unwise. Other basic peripheral variables such as the size of the target, required rate of return on the market portfolio, etc. could be answerable for this (WESTON and HALPERN, 1983).

Another important basis for comparing the value creation of a merger is the geographical characteristics of M\&A, meaning whether the merger target is a domestic or foreign company. The primary objective of this paper also aims to identify the potential merger effect of cross-country and domestic mergers on the acquirer firm. There have been uniform findings in the literature of domestic M\&A. Investors of the target firms have gained consistently (between 20-40\%) relative to the pre-announcement stock price. The finding of (Kaplan and Weisbach, 1992) shows that AAR of US target firms in domestic mergers were consecutively $29 \%$ during the period $1963-86,24 \%$ from 1972 to 1987 and from 1971 to 1982 it was almost $27 \%$. This result was found to be consistent at $21 \%$ in 1990 from the study of (Mulherin and Boone, 2000). The findings are somehow interesting in a sense that domestic mergers result in a higher gain compared to international mergers. This fact contradicts the FDI theory which predicts for 
cross-border M\&A that the acquirer should overcome the market imperfections and therefore achieve a higher gain. Empirical studies also show that there is severe inconsistency in the announcement gain achieved by the bidding firms in cross-border M\&As. Most of the studies (as far as we are aware of) exhibit negative returns for the investors, i.e. (Walker, 2000); (Mitchell and Stafford, 2000); (Sirower, 1997); (Healy et al., 1992) and some other present nil or insignificant positive AR for the acquirer (Eckbo and Thorburn, 2000); (Maquieira et al., 1998); (Schwert, 2000). The relatively smaller size of the target firms could be a possible reason of the lower gains for bidders as identified by (Loderer and Martin, 1990). Studies conducted to identify the wealth effect of mergers between UK and US firms during the period 1971-80 by (Conn and Connell, 1990) found that US target firm's investors gained more compared to the UK investors $(40 \%$ against 18\%). Whereas (Danbolt et al., 2002) suggested there is no substantial statistical deviation of the short-term AR between the UK target firms involved in domestic and cross-border M\&As (18.46\% against 19.68\%). Both (Wansley et al., 1983 ) and (Dewenter, 1995) argued that the return effect of cross-border mergers is due to the imbursement system, the bid result and the industry type regardless of the basic differentiations in the AR level. Another issue addressed by (Healy et al., 1997) and (Agrawal and Mandelker, 1987) is that bidding firms with substantial shareholding by the firm's management experience higher M\&A return, proving the existence of the agency theory (Goergen and Renneboog, 2004). Return variability on the basis of the nature of the ownership of the target firm is pointed by (Doukas and Travlos, 1988). They discovered that an acquisition of the domestic target firms by UK acquiring firms results in a significant negative announcement return whereas a cross-border public acquisition results in a zero return. But the scenario is completely opposite in the case of a domestic and crossborder private acquisition with a substantial positive AR. They also find in their study of US firms that multinational firms already doing business in the target firm's country experience a negative announcement return on the firm's common stock. However, firms acquiring target firms in a new country invariably experience statistically significant positive return on the merger announcement. Another interesting finding from the study is that investors gain more when the firm's expansion has taken place in less developed countries, less advanced and negatively correlated with their home country (USA) economy.

This part of the literature review briefly exhibits findings of the prominent research conducted with a view to identify the domestic and cross-border merger effect on investor's wealth creation. The following table summarises the significant chronological research findings of international and domestic M\&A effects. Almost all the research invariably concluded that in both domestic and international M\&As the target firms are the ultimate gainer. Applying the market model, (Firth, 1980) discovers a substantial negative CAARs of $-6.3 \%$ for the 
bidding firms at the announcement month. Similar findings are presented by (Barnes, 1984) in that the initial announcement return (CAAR) is positive for bidding firms in foreign acquisitions but negative in the longer horizon. (Franks and Harris, 1989) imply the same standard with a broader sample size of 1,048 acquirer firms covering the time horizon of 30 years (1955-85) and find a mixed result of substantial negative yields of (12.6\%) over the 2 year period following the acquisition event when $\mathrm{MM}$ is used but a significant positive return of $4.5 \%$ when the CAPM is used as the standard. Findings of (Limmack, 1991) via use of three different models give a possible reason of this difference, as he argues that the high positive alpha value in the pre-announcement period from the market model could be the possible reason, though he also suggest that a selection of the models have a negligible impact on the outcome. (Higson and Elliott, 1993) and (Kennedy and Limmack, 1996) find significant bidders' gain in the preannouncement period but insignificant return in the post-announcement period. Studies by (Gregory, 1997); (Conn and Connell, 1990); (Shaked et al., 1991); (Cakici et al., 1996) have also shown similar findings that in both national and international M\&As, target firms' stockholders are the ultimate gainers. (Sudarsanam et al., 1996) try to explain the synergic effect of M\&A by using the variable of a relative liquidity and growth opportunities and finds that there have been positive operational, financial and managerial synergic effects for both the bidding and target firms but as the merger gain in terms of the stock return is concerned, bidding firms' stockholders experience a significant negative CAR $(-4.04 \%$ between the period -20 to +40 ; for period specification, please refer to Section 2.4).

Tab. 1 Empirical study finding of cross-border and domestic M\&A

\begin{tabular}{|c|c|c|c|c|}
\hline Study & $\begin{array}{l}\text { Sample } \\
\text { size \& } \\
\text { Country }\end{array}$ & $\begin{array}{l}\text { Sample } \\
\text { period }\end{array}$ & $\begin{array}{l}\text { Model } \\
\text { Used }\end{array}$ & Summary Findings \\
\hline (Firth, 1980) & 434, UK & $\begin{array}{l}1969 \text { to } \\
1975\end{array}$ & $\begin{array}{l}\text { Market } \\
\text { Model }\end{array}$ & $\begin{array}{l}\text { M\&A resulted more announcement gain } \\
\text { (positive CAAR) for the target company } \\
\text { stockholder that that of the acquirer } \\
\text { (Negative CAAR). }\end{array}$ \\
\hline (Barnes, 1984) & $39, \mathrm{UK}$ & $\begin{array}{l}1974 \text { to } \\
1976\end{array}$ & $\begin{array}{l}\text { Market } \\
\text { Model }\end{array}$ & $\begin{array}{l}\text { Instant insignificant gain on the merger } \\
\text { announcement where as significant after } \\
\text { merger loss in the long-run. }\end{array}$ \\
\hline $\begin{array}{l}\text { (Franks and } \\
\text { Harris, 1989) }\end{array}$ & $\begin{array}{l}1,800 \\
\mathrm{UK}\end{array}$ & $\begin{array}{l}1955 \text { to } \\
1985\end{array}$ & $\begin{array}{l}\text { MM\& } \\
(\mathrm{CAPM})\end{array}$ & $\begin{array}{l}\text { Target firm's investors' gain appears to } \\
\text { be superior to that of the bidding firms. }\end{array}$ \\
\hline $\begin{array}{l}\text { (Limmack, } \\
\text { 1991) }\end{array}$ & $\begin{array}{l}1,284 \\
\text { UK }\end{array}$ & $\begin{array}{l}1977 \text { to } \\
1986 .\end{array}$ & $\begin{array}{l}\text { Market } \\
\text { Model }\end{array}$ & $\begin{array}{l}\text { The pre-bid wealth creation was positive } \\
\text { for both the acquirer and target firm } \\
\text { whereas post-bid return is positive for } \\
\text { the target and negative for the bidder. }\end{array}$ \\
\hline
\end{tabular}




\begin{tabular}{|c|c|c|c|c|}
\hline Study & $\begin{array}{l}\text { Sample } \\
\text { size \& } \\
\text { Country }\end{array}$ & $\begin{array}{l}\text { Sample } \\
\text { period }\end{array}$ & $\begin{array}{l}\text { Model } \\
\text { Used }\end{array}$ & Summary Findings \\
\hline $\begin{array}{l}\text { (Higson and } \\
\text { Elliott, 1993) }\end{array}$ & $830, \mathrm{UK}$ & $\begin{array}{l}1975 \text { to } \\
1990\end{array}$ & $\begin{array}{l}\text { Market } \\
\text { Model }\end{array}$ & $\begin{array}{l}\text { No significant evidence of long-term } \\
\text { negative abnormal gain for the bidding } \\
\text { firm. }\end{array}$ \\
\hline $\begin{array}{l}\text { (Kennedy and } \\
\text { Limmack, } \\
\text { 1996) }\end{array}$ & $345, \mathrm{UK}$ & $\begin{array}{l}1980 \text { to } \\
1989\end{array}$ & $\begin{array}{l}\text { Market } \\
\text { Model }\end{array}$ & $\begin{array}{l}\text { Negative abnormal return in pre-bid } \\
\text { period for target firm against positive } \\
\text { return of bidder however reverses result } \\
\text { experienced in post-bid period. }\end{array}$ \\
\hline $\begin{array}{l}\text { (Gregory, } \\
1997 \text { ) }\end{array}$ & 420, UK & $\begin{array}{l}1984 \text { to } \\
1992\end{array}$ & $\begin{array}{l}\text { MM\& } \\
\text { (CAPM) }\end{array}$ & $\begin{array}{l}\text { Substantial negative APIs and CAARs } \\
\text { for the } 24 \text { months post-takeover. Long } \\
\text { horizon stockholder's wealth creation in } \\
\text { domestic acquisition has been } \\
\text { significantly negative. }\end{array}$ \\
\hline $\begin{array}{l}\text { (Conn and } \\
\text { Connell, 1990) }\end{array}$ & $\begin{array}{l}73, \mathrm{UK} \& \\
\text { USA }\end{array}$ & $\begin{array}{l}1971 \text { to } \\
1980\end{array}$ & $\begin{array}{l}\text { Market } \\
\text { Model } \\
\text { (IMM) }\end{array}$ & $\begin{array}{l}\text { CAR is significantly positive for both } \\
\text { target and acquirer firms in USA\&UK } \\
\text { for the pre-\& post-merger period but US } \\
\text { firms outperform UK firms. }\end{array}$ \\
\hline $\begin{array}{l}\text { (Harris and } \\
\text { Ravenscraft, } \\
\text { 1991) }\end{array}$ & $\begin{array}{l}1273 \\
\text { USA }\end{array}$ & $\begin{array}{l}1970 \text { to } \\
1987\end{array}$ & $\begin{array}{l}\text { Market } \\
\text { Model }\end{array}$ & $\begin{array}{l}\text { Target company stockholders' gains are } \\
\text { substantially higher in international } \\
\text { takeovers compared to domestic } \\
\text { acquisitions. }\end{array}$ \\
\hline $\begin{array}{l}\text { (Shaked et al., } \\
\text { 1991) }\end{array}$ & $\begin{array}{l}29(\mathrm{~F}) \& \\
83(\mathrm{D}) \\
\text { USA }\end{array}$ & $\begin{array}{l}1975 \text { to } \\
1983\end{array}$ & $\begin{array}{l}\text { Market } \\
\text { Model }\end{array}$ & $\begin{array}{l}\text { Stockholders gain more returns in cross } \\
\text { border acquisition announcement than } \\
\text { they obtain from similar national merger } \\
\text { declarations. }\end{array}$ \\
\hline $\begin{array}{l}\text { (Cakici et al., } \\
\text { 1996) }\end{array}$ & 195, USA & $\begin{array}{l}1983 \text { to } \\
1992\end{array}$ & $\begin{array}{l}\text { Market } \\
\text { Model }\end{array}$ & $\begin{array}{l}\text { Foreign acquirers achieve positive } \\
\text { significant AR of targets in the United } \\
\text { States; whereas, US. bidders do not } \\
\text { experience any gain from their } \\
\text { acquisition of international target }\end{array}$ \\
\hline $\begin{array}{l}\text { (Sudarsanam } \\
\text { et al., 1996) }\end{array}$ & 429, UK & $\begin{array}{l}1980 \text { to } \\
1990\end{array}$ & $\begin{array}{l}\text { MKT \& } \\
\text { MKT } \\
\text { Adjusted } \\
\text { Model }\end{array}$ & $\begin{array}{l}\text { Target firm's shareholders experience } \\
\text { significant risk adjusted gain before \& } \\
\text { after merger announcement than that of } \\
\text { bidding firms. }\end{array}$ \\
\hline $\begin{array}{l}\text { (Aw and } \\
\text { Chatterjee, } \\
\text { 2004) }\end{array}$ & 79, UK & $\begin{array}{l}1991 \text { to } \\
1996\end{array}$ & $\begin{array}{l}\text { MM \& } \\
\text { MAR }\end{array}$ & $\begin{array}{l}\text { CAR value for UK bidding firms is less } \\
\text { negative for domestic merger than that of } \\
\text { international merger. }\end{array}$ \\
\hline
\end{tabular}

Source: Author's review of several relevant articles (cited in the study column, references are listed at the end). 


\section{Methodology}

Although there have been numerous key event studies conducted over the last five decades, the core statistical design for analysing the event has not experienced major modifications from the conventional model introduced by (Fama et al., 1969). Determining the sample securities' AAR and CAAR around the pre-event and post-event are still the main attention. However, two important features have been introduced to the methodology. First, adoption of the daily stock return rather than the monthly return which presume to generate more accurate analysis of the event's effect. Second, the more advanced technique to calculate the abnormal return and to adjust the statistical significance have been introduced to measure the long horizontal effect, parallel with the development of the 'Fama-French 3factor model' (Kothari and Warner, 2004).

\subsection{Research question and hypothesis development}

The main research question of this paper is to identify whether there is any significant stock price reaction between UK acquirer firms involved in domestic (local) mergers and international (cross-border) mergers. Several prior studies have addressed this issue of the stock return/wealth/gain performance variance of both domestic and international M\&As in terms of AR. Although FDI theoretical framework suggests that firms will gain in international M\&As by exploiting market imperfections (Morck and Yeung, 1992), the empirical evidence in most of the cases exhibit inconstant or opposite results in terms of the market gain (Kaplan and Weisbach, 1992). Studies by (Conn et al., 2005), (Goergen and Renneboog, 2004), (Kang and Johansson, 2000) and others found statistically significant positive AR in cross-border M\&A whereas (Aw and Chatterjee, 2004), (Datta and Puia, 1995), (Mathur et al., 1994), (Eun et al., 1996) found statistically significant negative AR. Similarly, in the case of domestic mergers unanimous research findings are also presented. Studies by (Firth, 1980), (Barnes, 1984), (Higson and Elliott, 1998) demonstrate a negative post-merger return in domestic acquisitions while (Conn et al., 2005), (Sudarsanam et al., 1996) shows a significant positive AR. That guides us to the following hypothesis.

Null hypothesis:

- H0a: No significant abnormal return is (positively or negatively) associated with the local takeover announcement.

- H0b: No significant abnormal return is (positively or negatively) associated with the global takeover announcement.

Alternative hypothesis:

- H1a: There is a substantial abnormal return when there is a home takeover (positive or negative). 
- H1b: There is a substantial abnormal return when there is a cross-border takeover (positive or negative).

\subsection{Data selection}

We only concentrate on the return effect of the UK acquirer firms engaging in local and international M\&As. Effects on the target firms are not considered. For this purpose, the total of $100 \mathrm{UK}$ actively traded public firms (50 firms involved in local mergers and 50 firms engaged in cross-border mergers) were selected randomly as a sample involved in the M\&A between January 2015 to December 2016 along with the M\&A event announcement data from ' $\mathrm{http} / / /$ banker.thomsonib.com/ta'. Daily stock returns for the bidding firms in the sample and the daily market return (FTSE-All Share Index) from January 2015 to December 2016 were obtained from the same above source. Firms with infrequent trading records were intentionally omitted from the sample to avoid the 'thin trading' problem.

\subsection{The choice of an event date}

The most critical part of the even study is to identify the event date. One way is the maiden public announce date of M\&A. Any abnormal share price movement before this date would suggest the probable information leakage (WESTON and HALPERN, 1983). Instead of this, the actual M\&A event date could be considered as the event date to negotiate any ambiguity regarding measuring the market efficiency (Yagil, 1996). We have considered public announcement date of M\&A as an event date consistent with (Uddin and Boateng, 2009, Kohli and Mann, 2012, Boateng et al., 2008).

\subsection{Model used to measure AAR and CAAR}

To identify the abnormal return associated with the event, we have split the data into two phases: the estimation phase and the event phase. We have considered the estimation period of $t-10$ to $t-100$ and the event period of $t-5$ to $t+5$, where $t$ is the announcement date. Log-returns of both the daily market return (FTSE All-Share Index) and the daily closing stock price are calculated using the following formula (1) after adjusting for bank holidays.

$$
R_{t}=\ln \left(\frac{P_{t}}{P_{t-1}}\right)
$$

We have used the market model (MM), the classic asset pricing model used by (Fama et al., 1969), where expected return (normal return without the event effect) is determined by the following ordinary least square (OLS) method.

$$
R_{i t}=\alpha_{i}+\beta_{i} R_{m t}+\varepsilon_{i t},
$$


where, $E\left(R_{i t}\right)$ is the expected return on stock, alpha is the intercept and beta is the coefficient (slope) determined by the OLS regression of the stock return against the market index return, conducted for each firms' stock for the estimation period t $=-100$ to $-10 . R_{m t}$ is the market index return. Abnormal return is calculated for each day of the event period by subtracting the expected return (derived through the OLS equation) from the actual realised return. The formula used is given below; where $A R_{i t}$ stands for the abnormal return, $R_{i t}$ is the realized return and $\mathrm{E}\left(\mathrm{R}_{\mathrm{i}, \mathrm{t}}\right)$ is the expected return.

$$
A R_{i t}=R_{i t}-\left(\alpha_{i}+\beta_{i} R_{m t}\right)=R_{i t}-E\left(R_{i t}\right)
$$

The average abnormal return (AAR) is calculated by averaging all the ARs of all the observation (firms) for each of the event day $(t=-5$ to +5$)$ by using the following formula to test the statistical significance of abnormality; where $\mathrm{AR}_{\mathrm{jt}}$ is the abnormal return and $\mathrm{N}$ is the sample size.

$$
A A R_{t}=\frac{1}{N t} \sum_{i=1}^{N} A R_{i t}
$$

We have segregated the event period ( $t_{-5}$ to $t_{+5}$ ) into three different event windows in order to analyse the stock return reaction which indicates the investor's reaction to the news of M\&A. The three event windows are: pre-event period $\left(t_{-1}\right.$ to $\left.t_{-5}\right)$, event window $\left(t_{0}\right.$ to $\left.t_{+1}\right)$ and post-event window $\left(t_{+2}\right.$ to $\left.t_{+5}\right)$. We calculate cumulative average return (CAR) for each event window of each observation using the following formula:

$$
\operatorname{CAR}_{\left(T_{1}, T_{2}\right)}=\sum_{t=T_{1}}^{T_{2}} A R_{i t}
$$

Like AAR, we compute the cumulative average abnormal return (CAAR) which is the average of CAR of each observation.

\subsection{Testing the hypothesis}

We have used the t- test statistics to test the hypothesis. A statistic of this system is broadly practiced in event studies such as (Aw and Chatterjee, 2004), (Sudarsanam et al., 1996), (Barnes, 1984), (Franks and Harris, 1989). Test measures, such as the CAAR and AAR, are calculated and tested at the $1 \%$ and $5 \%$ significance level. ARR/CAAR value greater than 0 (zero) with a statistical significance (test statistic surpasses the critical value of the t-table, conforming to the 5\% and $1 \%$ significance level) indicates a positive investors' reaction to the M\&A news and negative reaction in the case the value is less than 0 (zero) with a statistical 
significance. In both cases the null hypothesis will be rejected. The t-statistics formula used for testing the hypothesis is:

$$
t_{C A R}=C A A R_{i \tau} /\left(\sigma\left(C A R_{i \tau}\right) / \sqrt{N}\right),
$$

where $\mathrm{t}=\mathrm{t}$-stat, $\mathrm{CAR}=$ cumulative abnormal return, $\sigma=$ standard deviation of returns, $\mathrm{N}$ is the number of observations.

The presented study uses the two-tailed test to test the impact of M\&A announcement to the share price of acquirers. The critical value of the two-tailed test significance level should be seen in the t-distribution table with 49 degrees of freedom to test the impact of the 'home' and 'cross-border' takeover announcement partially. To examine the significant impact, this study uses the decision rule as follows:

\section{Tab. 2 Decision rule of the two-tailed test}

\begin{tabular}{ll}
\hline Criteria & Decision \\
\hline -t-table $<=$ t-stat $<=$ t-table & Cannot reject the null hypothesis \\
t-stat $<$-t-table & Reject the null hypothesis \\
t-stat $>$ t-table & Reject the null hypothesis \\
\hline
\end{tabular}

Source: (Lind et al., 2000).

\section{Results and Analysis}

The results and analysis part are divided into two sections. First, we analyse the stock return effect where the UK firms are involved in the domestic M\&A and second, we consider the UK firms involved in the cross-border M\&A. In both cases, the CAAR and AAR values will be tested for significance to draw a conclusion whether there is any significant return associated with the M\&A event.

\subsection{UK firms involved in domestic M\&A}

The following table shows the mean abnormal return of all the firms in the event periods which are statistically tested for significance. There are no significant abnormal returns found to be associated with the pre- and post-M\&A event at 5\% and $1 \%$ significance levels.

Tab. 3 AAR with significance (domestic M\&A)

\begin{tabular}{|c|c|c|c|c|c|c|c|}
\hline \multirow{2}{*}{$\begin{array}{l}\text { Event } \\
\text { days }\end{array}$} & \multirow{2}{*}{$\begin{array}{l}\text { AAR } \\
\text { (in \%) }\end{array}$} & \multirow{2}{*}{$\begin{array}{l}\text { t- } \\
\text { statistics }\end{array}$} & \multicolumn{2}{|c|}{ T-table value } & \multirow{2}{*}{ Comparison } & \multirow{2}{*}{$\begin{array}{l}P \text { - } \\
\text { value }\end{array}$} & \multirow{2}{*}{ Significance } \\
\hline & & & $1 \%$ & $5 \%$ & & & \\
\hline-5 & 0.1926 & 0.4101 & 2.678 & 2.009 & $\mathrm{t}$ stats $<\mathrm{t}$ table & 0.6835 & $\begin{array}{l}\text { Not significant } \\
\text { at } \mathrm{p}<.05\end{array}$ \\
\hline-4 & 0.1574 & 0.7683 & 2.678 & 2.009 & $\mathrm{t}$ stats $<\mathrm{t}$ table & 0.4460 & Not significant \\
\hline-3 & -0.0334 & -0.1281 & -2.678 & -2.009 & $\mathrm{t}$ stats $>\mathrm{t}$ table & 0.8987 & Not significant \\
\hline-2 & 0.0586 & 0.1658 & 2.678 & 2.009 & $\mathrm{t}$ stats $<\mathrm{t}$ table & 0.8691 & Not significant \\
\hline
\end{tabular}


Adnan, ATM: Home vs. Cross-Border Takeovers: Is There Any Difference in Investor Perception?

\begin{tabular}{|c|c|c|c|c|c|c|c|}
\hline \multirow{2}{*}{$\begin{array}{l}\text { Event } \\
\text { days }\end{array}$} & \multirow{2}{*}{ AAR } & \multirow{2}{*}{$\begin{array}{l}\text { t- } \\
\text { statistics }\end{array}$} & \multicolumn{2}{|c|}{ T-table value } & \multirow{2}{*}{ Comparison } & \multirow{2}{*}{$\begin{array}{l}P \text { - } \\
\text { value }\end{array}$} & \multirow{2}{*}{ Significance } \\
\hline & & & $1 \%$ & $5 \%$ & & & \\
\hline-1 & 0.0702 & 0.3259 & 2.678 & 2.009 & $\mathrm{t}$ stats $<\mathrm{t}$ table & 0.7460 & Not significant \\
\hline 0 & 0.5702 & 1.7740 & 2.678 & 2.009 & $\mathrm{t}$ stats $<\mathrm{t}$ table & 0.0823 & Not significant \\
\hline 1 & 0.3816 & 1.1463 & 2.678 & 2.009 & $\mathrm{t}$ stats $<\mathrm{t}$ table & 0.2573 & Not significant \\
\hline 2 & -0.2085 & -0.7209 & -2.678 & -2.009 & $\mathrm{t}$ stats $>\mathrm{t}$ table & 0.4750 & Not significant \\
\hline 3 & 0.1904 & 0.8406 & 2.678 & 2.009 & $\mathrm{t}$ stats $<\mathrm{t}$ table & 0.4047 & Not significant \\
\hline 4 & -0.3123 & -0.9503 & -2.678 & -2.009 & t stats $>\mathrm{t}$ table & 0.3468 & Not significant \\
\hline 5 & -0.0719 & -0.2625 & -2.678 & -2.009 & $\mathrm{t}$ stats $>\mathrm{t}$ table & 0.7944 & Not significant \\
\hline
\end{tabular}

Source: Authorial calculation.

From Figure 1 it is clear that AAR is highly inconsistent and volatile. There is no significant statistical evidence of any possible information leakage or insider trading associated with the merger event. The highest return in the pre-merger period is $0.19 \%$ on the day $\mathrm{t}-5$ followed by $0.16 \%$ on the day $\mathrm{t}-4$. The post-merger AAR returns are mostly negative apart from the day $\mathrm{t}+3$.

\section{Tab. 4 CAAR value at the three event windows (domestic M\&A)}

\begin{tabular}{|c|c|c|c|c|c|c|c|}
\hline \multirow{2}{*}{$\begin{array}{l}\text { Event } \\
\text { Window }\end{array}$} & \multirow{2}{*}{$\begin{array}{l}\text { CAAR } \\
\text { (in \%) }\end{array}$} & \multirow{2}{*}{ t-stats } & \multicolumn{2}{|c|}{ t-table } & \multirow{2}{*}{ Comparison } & \multirow{2}{*}{$\begin{array}{l}P \text { - } \\
\text { value }\end{array}$} & \multirow{2}{*}{ Significance } \\
\hline & & & $1 \%$ & $5 \%$ & & & \\
\hline $\begin{array}{l}(-5 \text { to }-1) \\
\text { pre-event }\end{array}$ & 0.4455 & 0.5793 & 2.678 & 2.009 & t stats $<$ t table & 0.5650 & $\begin{array}{l}\text { The result } \\
\text { is not significa } \\
\text { nt at } p<0.05\end{array}$ \\
\hline $\begin{array}{l}(0 \text { to }+1) \\
\text { event }\end{array}$ & 0.9518 & 2.3967 & 2.678 & 2.009 & t stats $<$ t table & 0.0204 & $\begin{array}{l}\text { The result is } \\
\text { significant at } \\
p<0.05\end{array}$ \\
\hline $\begin{array}{l}\text { ( }+2 \text { to } \\
+5) \text { post- } \\
\text { event }\end{array}$ & -0.4023 & -0.7146 & -2.678 & -2.009 & $\mathrm{t}$ stats $>\mathrm{t}$ table & 0.4787 & $\begin{array}{l}\text { The result } \\
\text { is not significa } \\
\text { nt at } p<0.05\end{array}$ \\
\hline
\end{tabular}

Source: Authorial calculation.

Table 4 also exhibits the pre-merger and post-merger CAAR values of the three individual event windows. The pre-merger CAAR $(t=-1,-5)$ value and the postmerger CAAR are reflecting insignificant surge of return, evident of the fact that there was no information asymmetry before announcement of the M\&A event. The event window $(\mathrm{t}=0,+1)$ produces a significant CAAR of $0.95 \%$ which is significant at $5 \%$ level and proves that the shareholders have reacted to the M\&A announcement, similar to the result found by (Markides and Ittner, 1994), (Cakici et al., 1996) and (Goergen and Renneboog, 2004). This was to be expected, since the early market response is defined as a 'transitory or temporary effect'. However, a negative CAAR is experienced in the post-event $(t=+2,+5)$ period 
that represents an immediate price adjustment following the initial overreaction. That also shows the semi-efficient market characteristics (Barnes, 1984) and also the fact that on local markets, investors enjoy more information availability compared to foreign markets. As the event window ( $\mathrm{t}-1$ to $\mathrm{t} 0$ ) presents the CAAR value greater than zero statistically and significant at $5 \%$ level, we can therefore reject the null hypothesis (H0a). Nevertheless, for the pre-event and post-event CAAR we cannot reject the null hypothesis.

\section{Fig. 1 AAR in \% (domestic M\&A)}

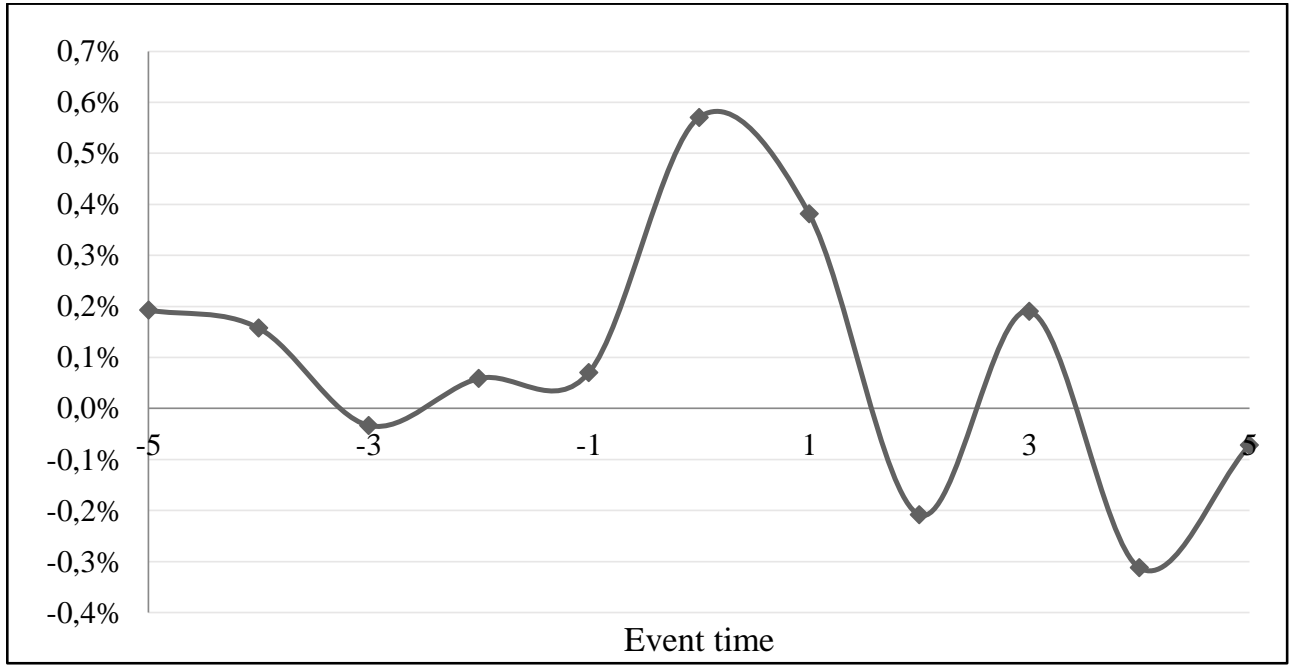

Source: Authorial calculation.

\subsection{UK firms involved in cross-border M\&A}

Table 5 exhibits the abnormal return around the cross-border merger event. There is no significant average abnormal return associated with the M\&A event. It is clearly evident from Figure 2 that prior to the announcement, there has been a positive flow of ARR from t-4 to t0. This can indicate possibility of a slight positive reaction from the investors or a narrow chance of an insider trading. But after that, the AAR's sharp decline also represents the mismatch of expectations among investors. The highest AAR is experienced on the event date at $1.61 \%$ though it is statistically insignificant both at $1 \%$ and $5 \%$ levels. Overall, ARR is highly volatile in the post-merger period. The result is consistent with the findings of (Roll, 1986), (Weitzel and Berns, 2006), (Hijzen et al., 2008) and (Bruner, 2002). 
Tab. 5 AAR (cross-border merger)

\begin{tabular}{|c|c|c|c|c|c|c|c|}
\hline \multirow{2}{*}{$\begin{array}{l}\text { Event } \\
\text { time }\end{array}$} & \multirow{2}{*}{$\begin{array}{l}\text { AAR } \\
\text { (in \%) }\end{array}$} & \multirow{2}{*}{ t-stats } & \multicolumn{2}{|c|}{ t-table } & \multirow{2}{*}{ Comparison } & \multirow{2}{*}{$\begin{array}{l}P \text { - } \\
\text { value }\end{array}$} & \multirow{2}{*}{ Significance } \\
\hline & & & $1 \%$ & $5 \%$ & & & \\
\hline-5 & 0.0895 & 0.3515 & 2.678 & 2.009 & t stats $<$ t table & 0.7267 & $\begin{array}{l}\text { The result } \\
\text { is not significant } \\
\text { at } \mathrm{p}< \\
0.01 / 0.05 / 0.10\end{array}$ \\
\hline-4 & -0.4363 & -1.0565 & -2.678 & -2.009 & t stats $>$ t table & 0.2962 & Insignificant \\
\hline-3 & -0.0382 & -0.1713 & -2.678 & -2.009 & t stats $>$ t table & 0.8649 & Insignificant \\
\hline-2 & 0.2141 & 0.8364 & 2.678 & 2.009 & t stats $<$ t table & 0.4071 & Insignificant \\
\hline-1 & 0.3996 & 1.5724 & 2.678 & 2.009 & t stats $<$ t table & 0.1223 & Insignificant \\
\hline 0 & 0.4195 & 1.6129 & 2.678 & 2.009 & t stats $<$ t table & 0.1132 & Insignificant \\
\hline 1 & 0.0222 & 0.0661 & 2.678 & 2.009 & t stats $<$ t table & 0.9477 & Insignificant \\
\hline 2 & -0.1641 & -0.6026 & -2.678 & -2.009 & t stats $>$ t table & 0.5500 & Insignificant \\
\hline 3 & 0.3349 & 0.9992 & 2.678 & 2.009 & t stats $<$ t table & 0.3227 & Insignificant \\
\hline 4 & -0.0081 & -0.0384 & -2.678 & -2.009 & t stats $>$ t table & 0.9698 & Insignificant \\
\hline 5 & 0.0698 & 0.2817 & 2.678 & 2.009 & t stats $<$ t table & 0.7794 & Insignificant \\
\hline
\end{tabular}

Source: Authorial calculation.

Tab. 6 CAAR (cross-border merger)

\begin{tabular}{|c|c|c|c|c|c|c|c|}
\hline \multirow{2}{*}{$\begin{array}{l}\text { Event } \\
\text { Window }\end{array}$} & \multirow[b]{2}{*}{ CAAR } & \multirow[b]{2}{*}{ t-stats } & \multicolumn{2}{|c|}{ t-table } & \multirow[b]{2}{*}{ Comparison } & \multirow[b]{2}{*}{ P-value } & \multirow[b]{2}{*}{ Significance } \\
\hline & & & $1 \%$ & $5 \%$ & & & \\
\hline $\begin{array}{l}(-5,-1) \text { pre- } \\
\text { event }\end{array}$ & 0.0024 & 0.2933 & 2.678 & 2.009 & t stats $<$ t table & 0.7706 & $\begin{array}{l}\text { The result } \\
\text { is not significa } \\
\text { nt at } \mathrm{p}< \\
0.01 / 0.05\end{array}$ \\
\hline $\begin{array}{l}(0,+1) \\
\text { event }\end{array}$ & 0.0044 & 1.1960 & 2.678 & 2.009 & t stats $<$ t table & 0.2375 & not significant \\
\hline $\begin{array}{l}(+2,+5) \\
\text { post-event }\end{array}$ & 0.0023 & 0.5778 & 2.678 & 2.009 & $\mathrm{t}$ stats $<\mathrm{t}$ table & 0.5661 & not significant \\
\hline
\end{tabular}

Source: Authorial calculation. 
The CAAR value associated with the three individual event windows (see Table 5) also shows an insignificant return. Although each of the windows presents a positive CAAR value, including the highest value in the event window $\mathrm{t}-1$ to t0 of $1.20 \%$, the returns are not statistically significant. This result is also consistent with the findings of (Gregory and McCorriston, 2005), (Campa and Hernando, 2004) and (Yook and McCabe, 1996).

As there is present no statistically significant CAAR value associated with the M\&A event, we therefore cannot reject the null hypothesis (HOb) of the nonexistence of a significant abnormal return for all the three event windows. When the cross-border and domestic mergers are compared, shareholders of the domestic acquirer seem to gain more than those of the cross-border acquirer, though only in the shorter event window. However, this argument is not conclusive.

\section{Fig. 2 AAR in \% (cross-border merger)}

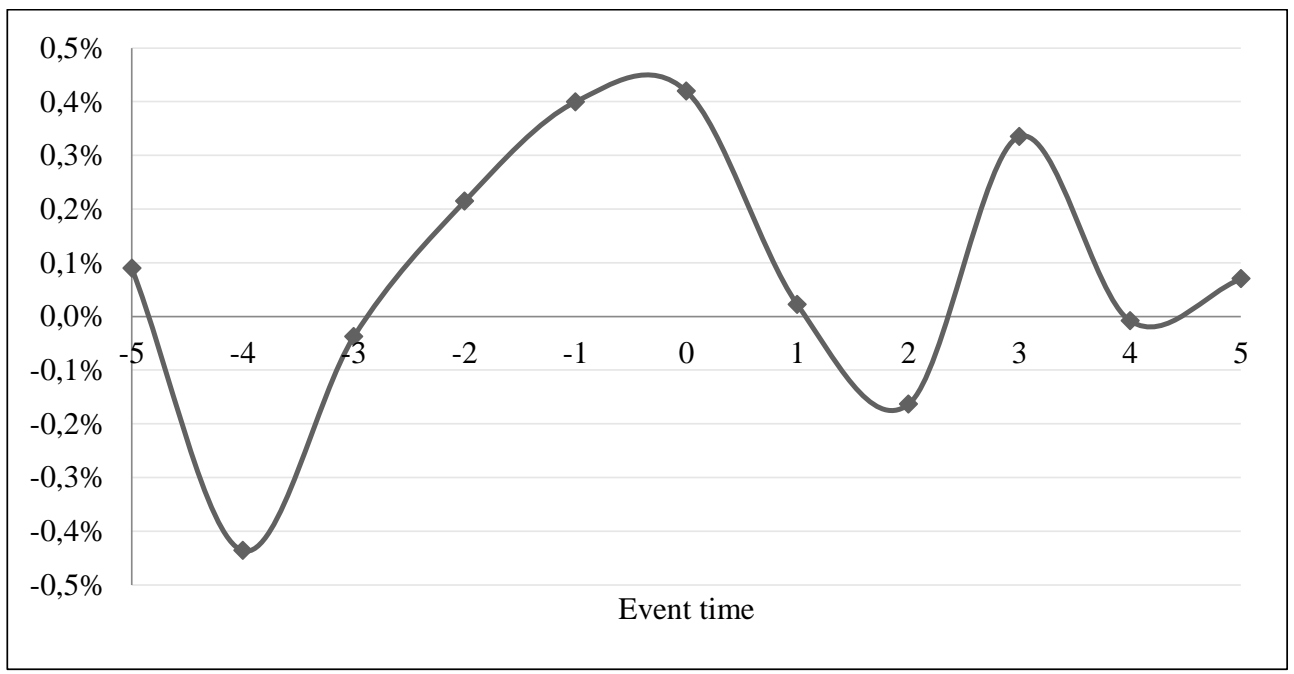

Source: Authorial calculation.

The first logical explanation could be the investors' perception about the higher payment margin for the acquisition, but that is not significant as suggested by (Servaes and Zenner, 1994), since international investors are likely to be offered a lucrative price to transfer their ownership. An alternative justification for the lesser AAR is that bidders in cross-border M\&As could expect entry barriers of a various nature that offset their advantages when entering unfamiliar markets (Weitzel and Berns, 2006, Hijzen et al., 2008). 


\section{Conclusion}

In this paper, we have used the event study to identify whether there is any significant investor reaction to the declaration of the merger and acquisition event reflected on the stock return. Another point of interest is to detect whether there is a significant difference in returns between the cross-border and domestic M\&As for the acquirer firm. In total $100 \mathrm{UK}$ firms were considered as a sample because the UK has been the second largest acquiring country globally after the USA. Our findings illustrate that for the domestic merger, the event announcement generates a positive reaction among the investors exhibited by a significant positive return on the event period. The result also suggests that market seems to be quite efficient as there was no significant AAR in the pre-merger and post-merger period due to information leakage or insider trading. Any unjustified hike in return was immediately adjusted following the merger announcement. Overall, inconsistent AAR is experienced over the shorter event horizon. In the case of cross-border M\&As, our findings show insignificant positive return (CAAR). Although there was a positive movement in AAR prior to the announcement indicative of a narrow probability of insider trading, the post-merger returns were volatile.

The outcome of this study has noteworthy implications for policymakers in the UK. From the economic strategy point of view, this research magnifies the significance of stimulation of the economic reforms in the UK due to the recent BREXIT tensions (Kohli and Mann, 2012). This study will facilitate UK investing firms to play a part and win the value arising from the global market for corporate control. Apart from the significant trading gain from mergers and acquisitions, the firms will be more motivated to achieve other firm-specific gains such as proprietary technology and managerial know-how. Despite its contribution, the study's limitations comprise randomly and deliberately selected samples to avoid the thin trading problem (we did not use any statistical sampling techniques) that might influence the outcome. On the other hand, this study did not take into account additional factors that may have an effect on prices, such as the firmspecific characteristics (size, market capitalisation, etc.), transaction-specific factors such as the form of the target, acquisition policy, geographical basis of the target firm and the payment methods and the macroeconomic conditions. An outcome generated from the sole country's sample may not be fit for generalisation. Our study simply tries to draw a statistically significant link between the stock return and the M\&A event. However, a possible future study could be devoted to finding the probable reason of the investors' reaction reflecting on the stock return on the long-term basis to assess the value generation of the UK acquirer of domestic and cross-border M\&A transactions. 


\section{References}

Agrawal, A., Mandelker, G. N., 1987. Managerial incentives and corporate investment and financing decisions. The journal of finance 42, 823-837. DOI: $10.2307 / 2328293$.

Andrage, G., Mitchell, M. L., Stafford, E., 2001. New evidence and perspectives on mergers. Journal of Economic Perspectives 15, 103-120. DOI: 10.1257/jep.15.2.103.

Ashley, J. W., 1962. Stock prices and changes in earnings and dividends: some empirical results. Journal of Political Economy 70, 82-85. DOI: 10.1086/258592.

Aw, M., Chatterjee, R. 2004. The performance of UK firms acquiring large crossborder and domestic takeover targets. Applied Financial Economics 14, 337-349. DOI: 10.1080/0960310042000211605.

Ball, R., Brown, P., 1968. An empirical evaluation of accounting income numbers. Journal of accounting research 6, 159-178. DOI: 10.2307/2490232.

Barnes, P., 1984. The effect of a merger on the share price of the attacker, revisited. Accounting and Business Research 15, 45-49. DOI: 10.1080/00014788.1984.9729243.

Boateng, A., Qian, W., Tianle, Y., 2008. Cross-border M\&As by Chinese firms: An analysis of strategic motives and performance. Thunderbird international business review 50, 259-270. DOI: 10.1002/tie.20203.

Brown, S. J., Warner, J. B., 1980. Measuring security price performance. Journal of financial economics 8, 205-258. DOI: 10.1016/0304-405x(80)90002-1.

Brown, S. J., Warner, J. B., 1985. Using daily stock returns: The case of event studies. Journal of financial economics 14, 3-31. DOI: 10.1016/0304405x(85)90042-x.

Bruner, R. F., 2002. Does M\&A pay? A survey of evidence for the decisionmaker. Journal of applied Finance 12, 48-68.

Cakici, N., Hessel, C., Tandon, K., 1996. Foreign acquisitions in the United States: Effect on shareholder wealth of foreign acquiring firms. Journal of Banking \& Finance 20, 307-329. DOI: 10.1016/0378-4266(94)00131-6.

Campa, J. M., Hernando, I., 2004. Shareholder value creation in European M\&As. European financial management 10, 47-81. DOI: $10.1111 / \mathrm{j} .1468$ 036x.2004.00240.x.

Capron, L., Mitchell, W., Swaminathan, A., 2001. Asset divestiture following horizontal acquisitions: A dynamic view. Strategic management journal 22, 817844. DOI: $10.1002 / \mathrm{smj} .175$. 
Child, J., Tse, D. K., 2001. China's transition and its implications for international business. Journal of international business studies 32, 5-21. DOI: 10.1057/palgrave.jibs.8490935.

Conn, R. L., 1985. A re-examination of merger studies that use the capital asset pricing model methodology. Cambridge Journal of Economics 9, 43-56. DOI: 10.1093/oxfordjournals.cje.a035563.

Conn, R. L., Connell, F., 1990. International mergers: returns to US and British firms. Journal of Business Finance \& Accounting 17, 689-711. DOI: 10.1111/j.1468-5957.1990.tb00568.x.

Conn, R. L., Cosh, A., Guest, P. M., Hughes, A., 2005. The impact on UK acquirers of domestic, cross-border, public and private acquisitions. Journal of Business Finance \& Accounting 32, 815-870. DOI: 10.1111/j.0306686x.2005.00615.x.

Corrado, C. J., 2011. Event studies: A methodology review. Accounting \& Finance 51, 207-234. DOI: 10.1111/j.1467-629x.2010.00375.x.

Danbolt, J., Hirst, I., Jones, E., 2002. Measuring growth opportunities. Applied Financial Economics 12, 203-212. DOI: 10.1080/09603100110090064.

Datta, D. K., Puia, G., 1995. Cross-border acquisitions: An examination of the influence of relatedness and cultural fit on shareholder value creation in US acquiring firms. MIR: Management International Review 35, 337-359.

Dewenter, K. L. 1995. Does the market react differently to domestic and foreign takeover announcements? Evidence from the US chemical and retail industries. Journal of Financial Economics 37, 421-441.

Dolley, J. C., 1933. Characteristics and procedure of common stock split-ups. Harvard Business Review 11, 316-326.

Doukas, J., Travlos, N. G., 1988. The effect of corporate multinationalism on shareholders' wealth: Evidence from international acquisitions. The Journal of Finance 43, 1161-1175. DOI: 10.1111/j.1540-6261.1988.tb03962.x.

Eckbo, B. E., 1983. Horizontal mergers, collusion, and stockholder wealth. Journal of financial Economics 11, 241-273. DOI: 10.1016/0304-405x(83)90013-2.

Eckbo, B. E., Thorburn, K. S., 2000. Gains to bidder firms revisited: domestic and foreign acquisitions in Canada. Journal of Financial and Quantitative Analysis 35, 1-25. DOI: $10.2307 / 2676236$.

Eun, C. S., Kolodny, R., Scheraga, C., 1996. Cross-border acquisitions and shareholder wealth: Tests of the synergy and internalization hypotheses. Journal of Banking \& Finance 20, 1559-1582. DOI: 10.1016/s0378-4266(96)00013-1.

Fama, E. F., 1991. Efficient capital markets: II. The journal of finance 46, 15751617. DOI: 10.1111/j.1540-6261.1991.tb04636.x. 
Fama, E. F., Fisher, L., Jensen, M. C., Roll, R., 1969. The adjustment of stock prices to new information. International economic review 10, 1-21. DOI: $10.2307 / 2525569$.

Fama, E. F., French, K. R., 1992. The cross-section of expected stock returns. The Journal of Finance 47, 427-465. DOI: 10.2307/2329112.

Firth, M., 1980. Takeovers, shareholder returns, and the theory of the firm. The Quarterly Journal of Economics 94, 235-260. DOI: 10.2307/1884539.

Franks, J. R., Harris, R. S., 1989. Shareholder wealth effects of corporate takeovers: the UK experience 1955-1985. Journal of financial Economics 23, 225249. DOI: $10.1016 / 0304-405 x(89) 90057-3$.

Goergen, M., Renneboog, L., 2004. Shareholder wealth effects of European domestic and cross-border takeover bids. European Financial Management 10, 945. DOI: 10.1111/j.1468-036x.2004.00239.x.

Gordon, M. J., Yagil, J., 1981. Financial gains from conglomerate mergers. Research in Finance 3, 42.

Gregory, A., 1997. An examination of the long run performance of UK acquiring firms. Journal of Business Finance \& Accounting 24, 971-1002. DOI: 10.1111/1468-5957.00146.

Gregory, A., McCorriston, S., 2005. Foreign acquisitions by UK limited companies: short-and long-run performance. Journal of Empirical Finance 12, 99125. DOI: 10.1016/j.jempfin.2003.10.003.

Haleblian, J., Finkelstein, S., 1999. The influence of organizational acquisition experience on acquisition performance: A behavioral learning perspective. Administrative Science Quarterly 44, 29-56. DOI: 10.2307/2667030.

Harris, R. S., Ravenscraft, D., 1991. The role of acquisitions in foreign direct investment: Evidence from the US stock market. The Journal of Finance 46, 825844. DOI: 10.1111/j.1540-6261.1991.tb03767.x.

Healy, P. M., Palepu, K. G., Ruback, R. S., 1992. Does corporate performance improve after mergers? Journal of financial economics 31, 135-175. DOI: 10.1016/0304-405x(92)90002-f.

Healy, P. M., Palepu, K. G., Rubeck, R. S., 1997. Which takeovers are profitable? Strategic or financial? Sloan Management Review 38, 45.

Higson, C., Elliott, J., 1993. The Returns to Takeovers: The UK Evidence, Institute of Finance and Accounting, London Business School.

Higson, C., Elliott, J., 1998. Post-takeover returns: The UK evidence. Journal of Empirical finance 5, 27-46. DOI: 10.1016/s0927-5398(96)00015-1. 
Hijzen, A., Görg, H., Manchin, M., 2008. Cross-border mergers and acquisitions and the role of trade costs. European Economic Review 52, 849-866. DOI: 10.1016/j.euroecorev.2007.07.002.

Hitt, M. A., Harrison, J. S., Ireland, R. D., 2001. Mergers \& acquisitions: A guide to creating value for stakeholders, Oxford University Press, Oxford.

Homburg, C., Bucerius, M., 2006. Is speed of integration really a success factor of mergers and acquisitions? An analysis of the role of internal and external relatedness. Strategic management journal 27, 347-367. DOI: 10.1002/smj.520.

Hudgins, S. C., Seifert, B., 1996. Stockholder returns and international acquisitions of financial firms: an emphasis on banking. Journal of Financial Services Research 10, 163-180. DOI: 10.1007/bf00115674.

Jarrell, G. A., Brickley, J. A., Netter, J. M., 1988. The market for corporate control: The empirical evidence since 1980. The Journal of Economic Perspectives 2, 49-68. DOI: 10.1257/jep.2.1.49.

Jarrell, G. A., Poulsen, A. B., 1989. Stock trading before the announcement of tender offers: Insider trading or market anticipation? Journal of Law, Economics, \& Organization 5, 225-248. DOI: 10.1093/oxfordjournals.jleo.a036969.

Kang, N.-H., Johansson, S., 2000. Cross-Border Mergers and Acquisitions. OECD Science, Technology and Industry Working Papers. DOI: 10.1787/18151965.

Kaplan, S. N., Weisbach, M. S., 1992. The success of acquisitions: Evidence from divestitures. The Journal of Finance 47, 107-138. DOI: 10.2307/2329092.

Kennedy, V., Limmack, R., 1996. Takeover activity, CEO turnover, and the market for corporate control. Journal of Business Finance \& Accounting 23, 267 285. DOI: 10.1111/j.1468-5957.1996.tb00912.x.

Kohli, R., Mann, B. J. S., 2012. Analyzing determinants of value creation in domestic and cross border acquisitions in India. International Business Review 21, 998-1016. DOI: 10.1016/j.ibusrev.2011.11.006.

Kothari, S., Warner, J. B., 1997. Measuring long-horizon security price performance. Journal of Financial Economics 43, 301-339. DOI: 10.1016/s0304405x(96)00899-9.

Kothari, S., Warner, J. B., 2004. The econometrics of event studies. SSRN Electronic Journal. DOI: 10.2139/ssrn.608601.

Kothari, S., Warner, J. B., 2005. Econometrics of Event Studies, Handbook of Corporate Finance: Empirical Corporate Finance (Handbooks in Finance Series, Elsevier/North-Holland), B. Espen Eckbo (ed.).

Lakonishok, J., Shleifer, A., Vishny, R. W., 1994. Contrarian investment, extrapolation, and risk. The journal of finance 49, 1541-1578. DOI: 10.1111/j.1540-6261.1994.tb04772.x. 
Limmack, R. J., 1991. Corporate mergers and shareholder wealth effects: 19771986. Accounting and Business Research 21, 239-252. DOI: 10.1080/00014788.1991.9729838.

Lind, D. A., Marchal, W. G., Wathen, S. A., Waite, C. A., 2000. Basic statistics for business and economics. Irwin/McGraw-Hill, Boston.

Loderer, C., Martin, K., 1990. Corporate acquisitions by listed firms: The experience of a comprehensive sample. Financial management 19, 17-33. DOI: $10.2307 / 3665607$.

Loughran, T., Vijh, A. M., 1997. Do long-term shareholders benefit from corporate acquisitions? The Journal of Finance 52, 1765-1790. DOI: $10.2307 / 2329464$.

Lubatkin, M., 1983. Mergers and the Performance of the Acquiring Firm. Academy of Management review 8, 218-225. DOI: 10.5465/amr.1983.4284724.

MacKinlay, A. C., 1997. Event studies in economics and finance. Journal of economic literature 35, 13-39.

Maquieira, C. P., Megginson, W. L., Nail, L., 1998. Wealth creation versus wealth redistributions in pure stock-for-stock mergers. Journal of Financial Economics 48, 3-33. DOI: 10.1016/s0304-405x(98)00002-6.

Markides, C. C., Ittner, C. D., 1994. Shareholder benefits from corporate international diversification: Evidence from US international acquisitions. Journal of International Business Studies 25, 343-366. DOI: 10.1057/palgrave.jibs.8490204.

Mathur, I., Rangan, N., Chhachhi, I., Sundaram, S., 1994. International acquisitions in the United States: Evidence from returns to foreign bidders. Managerial and Decision Economics 15, 107-118. DOI: 10.1002/mde.4090150203.

McWilliams, A., Siegel, D., 1997. Event studies in management research: Theoretical and empirical issues. Academy of management journal 40, 626-657. DOI: $10.2307 / 257056$.

Mitchell, M. L., Netter, J. M., 1994. The role of financial economics in securities fraud cases: Applications at the Securities and Exchange Commission. The Business Lawyer 49, 545-590.

Mitchell, M. L., Stafford, E., 2000. Managerial decisions and long-term stock price performance. The Journal of Business 73, 287-329. DOI: 10.1086/209645.

Moeller, S. B., Schlingemann, F. P., 2005. Global diversification and bidder gains: A comparison between cross-border and domestic acquisitions. Journal of Banking \& Finance 29, 533-564. DOI: 10.1016/s0378-4266(04)00047-0. 
Morck, R., Yeung, B., 1992. Internalization: an event study test. Journal of international economics 33, 41-56. DOI: 10.1016/0022-1996(92)90049-p.

Mulherin, J. H., Boone, A. L., 2000. Comparing acquisitions and divestitures. Journal of corporate finance 6, 117-139. DOI: 10.1016/s0929-1199(00)00010-9.

Myers, J. H., Bakay, A. J., 1948. Influence of stock split-ups on market price. Harvard Business Review 26, 251-255.

Myers, S. C., Majluf, N. S., 1984. Corporate financing and investment decisions when firms have information that investors do not have. Journal of financial economics 13, 187-221. DOI: 10.1016/0304-405x(84)90023-0.

Porter, M. E., 1980. Competitive strategy: Techniques for analyzing industries and competition. New York, 300.

Rau, P. R., Vermaelen, T., 1998. Glamour, value and the post-acquisition performance of acquiring firms. Journal of financial economics 49, 223-253. DOI: 10.1016/s0304-405x(98)00023-3.

Ravenscarft, D. J., Scherer, F. M., 1987. Life after takeover. The Journal of Industrial Economics 36, 147-156. DOI: 10.2307/2098409.

Roll, R., 1986. The hubris hypothesis of corporate takeovers. Journal of business 59, 197-216. DOI: 10.1086/296325.

Ruback, R. S., 1983. Assessing competition in the market for corporate acquisitions. Journal of Financial Economics 11, 141-153. DOI: 10.1016/0304405x(83)90008-9.

Rumelt, R. P., 1974. Strategy, structure, and economic performance. Harvard University Press, Cambridge.

Salter, M. S., Weinhold, W. A., 1979. Diversification through acquisition: Strategies for creating economic value. Free Press, New York.

Scherer, F., Ross, D., 1990. Economic Performance. Houghton-Mifflin, Boston.

Schwert, G. W., 1981a. The adjustment of stock prices to information about inflation. The Journal of Finance 36, 15-29. DOI: 10.1111/j.15406261.1981.tb03531.x.

Schwert, G. W., 1981b. Using financial data to measure effects of regulation. The Journal of Law and Economics 24, 121-158. DOI: 10.1086/466977.

Schwert, G. W., 2000. Hostility in takeovers: in the eyes of the beholder? The Journal of Finance 55, 2599-2640. DOI: 10.1111/0022-1082.00301.

Serra, A. P., 2002. Event study tests: a brief survey. Working papers de FAP No. 117.

Servaes, H., Zenner, M., 1994. Taxes and the returns to foreign acquisitions in the United States. Financial Management 23, 42-56. DOI: 10.2307/3666082. 
Shaked, I., Michel, A., McClain, D., 1991. The foreign acquirer bonanza: myth or reality? Journal of Business Finance \& Accounting 18, 431-447. DOI: 10.1111/j.1468-5957.1991.tb00605.x.

Shepherd, W. G., 1982. Causes of increased competition in the US economy, 1939-1980. The Review of Economics and Statistics 64, 613-626. DOI: $10.2307 / 1923946$.

Sirower, M. L., 1997. The synergy trap: How companies lose the acquisition game. The Free Press, New York.

Stillman, R., 1983. Examining antitrust policy towards horizontal mergers. Journal of Financial Economics 11, 225-240. DOI: 10.1016/0304-405x(83)90012-0.

Sudarsanam, S., Holl, P., Salami, A., 1996. Shareholder wealth gains in mergers: effect of synergy and ownership structure. Journal of Business Finance \& Accounting 23, 673-698. DOI: 10.1111/j.1468-5957.1996.tb01148.x.

Uddin, M., Boateng, A., 2009. An analysis of short-run performance of crossborder mergers and acquisitions: Evidence from the UK acquiring firms. Review of Accounting and Finance 8, 431-453. DOI: 10.1108/14757700911006967.

Walker, M. M., 2000. Corporate takeovers, strategic objectives, and acquiringfirm shareholder wealth. Financial management 29, 53-66. DOI: $10.2307 / 3666361$.

Wansley, J. W., Lane, W. R., Yang, H. C., 1983. Abnormal returns to acquired firms by type of acquisition and method of payment. Financial management 12, 16-22. DOI: $10.2307 / 3665512$.

Wansley, J. W., Lane, W. R., Yang, H. C. 1987. Gains to bidder firms in cash and securities transactions. Financial Review 22, 403-414. DOI: 10.1111/j.15406288.1987.tb01263.x.

Weitzel, U., Berns, S., 2006. Cross-border takeovers, corruption, and related aspects of governance. Journal of International Business Studies 37, 786-806. DOI: $10.1057 /$ palgrave.jibs.8400225.

Weston, J., Halpern, P., 1983. Corporate acquisitions: A theory of special cases? A review of event studies applied to acquisitions. The Journal of Finance 38, 297317. DOI: 10.1111/j.1540-6261.1983.tb02235.x.

Wübben, B., 2007. German mergers \& acquisitions in the USA: Transaction management and success. Springer Science \& Business Media, Berlin.

Yagil, J., 1996. Mergers and macro-economic factors. Review of financial economics 5, 181-190. DOI: 10.1016/s1058-3300(96)90014-2.

Yook, K. C., McCabe, G. M., 1996. The effect of international acquisitions on shareholders' wealth. The Mid-Atlantic Journal of Business 32, 5. 
Adnan, ATM: Home vs. Cross-Border Takeovers: Is There Any Difference in Investor Perception?

Zollo, M., Singh, H., 2004. Deliberate learning in corporate acquisitions: postacquisition strategies and integration capability in US bank mergers. Strategic Management Journal 25, 1233-1256. DOI: 10.1002/smj.426. 